\title{
Application of a semi-automatic micro-DBC analyzer system for screening basic amino acids in single grains
}

\author{
Marketta Saastamoinen and P. M. A. Tigerstedt \\ Finnpipette Ky/Labsystems Oy, Pulttitie 9, 00810 Helsinki 81 and Department \\ of Plant Breeding, University of Helsinki, 00710 Helsinki 71, Finland.
}

\begin{abstract}
The micro-DBC method (dye binding capacity) developed for single seeds is based on the FP-9 Analyzer System, which was originally developed for medical research. With a few extra devices it was adapted for seed protein micro-DBC determination. With the new analyzing system it is possible to calculate the amount of acid orange 12 dye bound by a single grain, determined per unit weight of the grain.

In the FP-9 Analyzer System, nine samples are handled simultaneously at all working stages. The system includes 9-tipped pipettes, a 9-tipped automatic diluter, scales, a grinder for 9 grains, a mixer for $8 \times 9$ samples and a centrifuge for $4 \times 9$ samples, and a photometer for 9 samples as well as a programmable desk calculator connected to it. The largest volume to be pipetted is $1 \mathrm{ml}$.

Twentyone barley lines, donated by Dr. L. Munck, Carlsberg Laboratory, Denmark, were studied with the FP-9 Analyzer System. From each barley line, 4-12 grains were studied. The correlation coefficient $(\mathrm{r})$ between their means and the results obtained by the macro-DBC system was $0.9600^{* * *}$. The coefficient of variation (C.V. \%) within the barley lines was $4.74-23.28 \%$. With homogeneous standard flour the coefficient of variation was $1.81-3.79 \%$ for eight cuvette blocks with 9 samples each. The micro-DBC system has been specially developed for plant breeding purposes. Screening of material can be carried out on single or half grains in segregating early generations $\left(\mathrm{F}_{2}-\mathrm{F}_{5}\right)$. Thus the cultivation of large line materials can partly be avoided.
\end{abstract}

\section{Introduction}

The use of cereals as a source of protein is restricted by their usually relatively low protein content and the low content of some amino acids. SAUER (1976) has reviewed the nutritional quality of seed protein. Lysine and threonine were found to be the first and second limiting amino acids respectively for barley, oats, rice, rye, triticale and wheat. In the breeding of cereals in view of altering their protein content and amino acid composition, the development of sufficiently rapid and exact analyzing methods is important. TALlBerG (1976) and KAuL et al. (1976) have compared existing methods of analyzing the lysine content of seed proteins. TALLBERG recommends the DBC method for screening as economical, rapid and exact. 
The DBC method has been adopted in plant breeding particularly for screening for lysine content (Hagberg and KarLsson 1969, Mossberg 1969). The method also has been used for analyses from a single or half a grain (KAUL et al. 1969). The development of the micro-DBC method presented in this paper is based mainly on earlier DBC methods. The analyzing techniques developed in medical research have enabled the development of the method.

\section{Material and methods}

\section{Material}

The study material consisted of 21 different barley lines (Hordeum vulgare L.) with varying nitrogen and lysine contents, donated by Dr. L. Munck of Carlsberg Laboratory, Denmark. The threshed seed samples were stored in plastic bags under laboratory conditions, and possible changes in the moisture content of the seeds were not controlled. In addition, homogeneous standard flour was used to study the precision of the method.

\section{Equipment}

The DBC (dye binding capacity) method was used in the experiments, adapted to the analyses of one grain. The FP-9 Analyzer System, developed originally for micro-analyses in medical research, was used as instrumentation. In the FP-9 Analyzer 9 samples (grains) are treated simultaneously. The FP-9 Analyzer System consists of 9-tipped pipettes, a 9-tipped automatic diluter, a balance, a grinder for 9 grains, a mixer for $8 \times 9$ samples, a centrifuge for $4 \times 9$ samples, a photometer for 9 samples, as well as a programmable desk calculator connected to it. Grain weight and absorbance measurements are fed to the calculator through an interface. Hence no data has to be collected manually (Fig 1). The tips of the pipettes, the test tubes

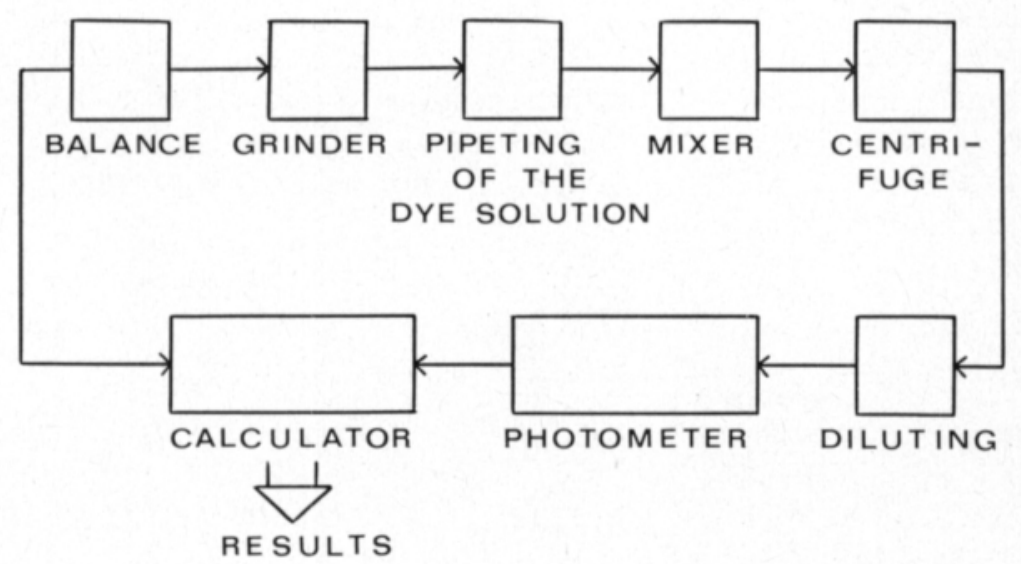

Fig. 1. Flow diagram of the FP-9 procedure to measure basic amino acids in single grains. 
and cuvettes are disposable. Nevertheless, it is possible to reuse them after thorough washing. The largest liquid volume to be pipetted is $1 \mathrm{ml}$.

The structure of the photometer differs from normal in that the path of light is vertical, travelling through the column of liquid in the cuvette encountering its free surface. The structure of the photometer leads to Beer's law, in modified form (Suovaniemi 1976)

$$
\mathrm{A}=\varepsilon \frac{\mathrm{m}}{\mathrm{a}},
$$

where $\mathrm{m}=$ mass

$a=$ cross surface area of cuvette

$\varepsilon=$ molar absorptivity $\left(\mathrm{cm}^{-1} \mathrm{~mol}^{-1} 1\right)$

The absorbance is directly proportional to the mass, and not to the concentration, as in an ordinary photometer.

\section{Reagents}

The dye solution contained $6.000 \mathrm{~g}$ of acid orange 12 dye, degree of purity approx. $80 \%$ (UDY 1971), $79.200 \mathrm{~g}$ of citric acid, $14.900 \mathrm{~g}$ of $\mathrm{Na}_{2} \mathrm{HPO}_{4} \times$ $2 \mathrm{H}_{2} \mathrm{O}$ and $0.300 \mathrm{~g}$ of thymol per litre. These concentrations proved suitable according to the pilot tests, in which different dye and buffer concentrations were used. Dye concentration was 4.5 times higher than in traditional dyebinding methods (Mossberg 1969, UDY 1971). $0.1 \%$ Triton $x-100$ solution was used as diluent.

\section{Procedure}

The seeds were weighed at first, one seed per test tube. Then an acid resistant RB-5 metal sphere, Ø $5 \mathrm{~mm}$, weighing $500 \mathrm{mg}$, was put into each test tube. Subsequently the seeds were ground for $4-8 \mathrm{~min}$. One block of test tubes (=9 test tubes in one block) can be ground in one run. The test tube block moves back and forth at high speed in the grinder and the metal sphere grinds the seed inside each tube.

After grinding, $1 \mathrm{ml}$ of dye solution was pipetted into each tube in the block using a 9-tipped pipette. The flour and dye solution were mixed for $1 \mathrm{~h}$ in the mixer. After the mixing, the test tubes were centrifuged at $4000 \mathrm{rpm}$ for $15 \mathrm{~min}$. The supernatants of the samples were diluted 200 -fold with $0.1 \%$ Triton $\mathrm{x}-100$ solution. The dilution was made in two steps; $100 \mu \mathrm{l}$ of supernatant and $900 \mu \mathrm{l} 0.1 \%$ Triton $\mathrm{x}-100$ were pipetted into test tubes and mixed, $50 \mu \mathrm{l}$ of this solution and $450 \mu \mathrm{l}$ of $0.1 \%$ Triton $\mathrm{x}-100$ were pipetted into the cuvette blocks for measurement. The same kind of dilution was made of the dye solution into a standard cuvette block. $0.1 \%$ Triton $\mathrm{x}-100$ was used as blank solution.

\section{Measurement and calculation}

The equation of the linear regression line between the mass and absorbance of the dye was used in calculation. A $488 \mathrm{~nm}$ filter was used in the measurements. Acid orange 12 dye has a broad absorption maximum between 470 and 490 $\mathrm{nm}$. The results were calculated using the following equations: 
$y_{i}=b x_{i}+a$

where

$\mathrm{y}_{\mathrm{s}}=\mathrm{bx}_{\mathrm{s}}+\mathrm{a}$

$\mathrm{b}=$ the coefficient of the linear regression line between the mass and absorbance of the dye

$\mathrm{a}=$ constant of the regression equation

$\mathrm{y}_{\mathrm{i}}=$ dye absorbance

$x_{i}=$ mass of the dye

$y_{\mathrm{s}}=$ absorbance of the sample

$\mathbf{x}_{\mathbf{s}}=$ mass of the dye not bound to the sample

The mass of dye in $1 \mathrm{ml}$ is:

$\bar{x}_{i}=200\left(\frac{\bar{y}_{i}-a}{b}\right)$.

where $\bar{y}_{i}=\left(\frac{y_{i 1}+y_{i 2}+\ldots y_{i 9}}{9}\right)$

The mass of dye bound by the protein of a single grain per unit weight of the grain is:

$\frac{\bar{x}_{i}-200\left(\frac{y_{s}-a}{b}\right)}{m_{s}}$

where $\mathrm{m}_{\mathrm{s}}=$ mass of the grain.

A micro-DBC determination was done of each barley line, using 4-12 grains, and the results were compared to the results of the macro-DBC method obtained by Munck.

\section{Results}

The regression line between the mass and absorbance of the dye is linear up to an absorbance value of 2.000 (Fig. 2). The equation of the regression line is valid with a $99.86 \%$ probability. This regression equation can be used in all measurements performed by photometers of the FP-9 Analyzer System. The precision of the method was tested using a homogeneous standard flour. Statistical details of the results are given in Table 1. The deviations can be

Table 1. Amount of dye bound by Pro Meter Mk II standard flour (weighed approx. $60 \mathrm{mg} / \mathrm{a}$ tube).

\begin{tabular}{ccccc}
\hline $\begin{array}{l}\text { Cuvette } \\
\text { block no. }\end{array}$ & $\overline{4}$ & $\begin{array}{c}\text { Amount of bound dye, } \mu \mathrm{g} / \mathrm{mg} \text { flour } \\
\max .\end{array}$ & min. & C.V. \% \\
\hline 1. & 43.09 & 46.40 & 41.52 & 3.51 \\
2. & 42.88 & 46.03 & 41.53 & 3.21 \\
3. & 42.17 & 45.21 & 39.73 & 3.79 \\
4. & 42.71 & 44.02 & 41.36 & 2.60 \\
5. & 42.41 & 44.10 & 40.98 & 2.39 \\
6. & 42.42 & 43.82 & 41.34 & 1.81 \\
7. & 42.40 & 43.60 & 40.53 & 2.19 \\
8. & 42.27 & 43.67 & 40.47 & 2.78 \\
\hline$\overline{\mathrm{x}}$ & 42.54 & 46.40 & 39.73 & 2.80 \\
\hline
\end{tabular}


considered insignificant, since in barley the dye bound in one $\mathrm{mg}$ of flour varies greatly among the different genotypes.

Great variation exists among different barley lines in their dye-binding capacity (Table 2), although the number of seeds examined per barley line was low. The variation within some barley lines was quite high. In most lines the correlation coefficients between the seed size and the amount of bound dye, $\mu \mathrm{g} / \mathrm{mg}$ flour (seed) are negative. A high positive correlation was obtained between the average dye-binding capacity of the grains of the barley lines and the results obtained by Munck (Fig. 3). The points are somewhat dispersed, but it should be taken into consideration that the results obtained by the FP-9 Analyzer are the means of 4-12 grains, whereas Munck's results have been obtained by the macro-DBC method and are thus the means of several hundred grains. In addition, the moisture content of the grains was not controlled in the analyses made from a single grain which may have caused some errors in the results.
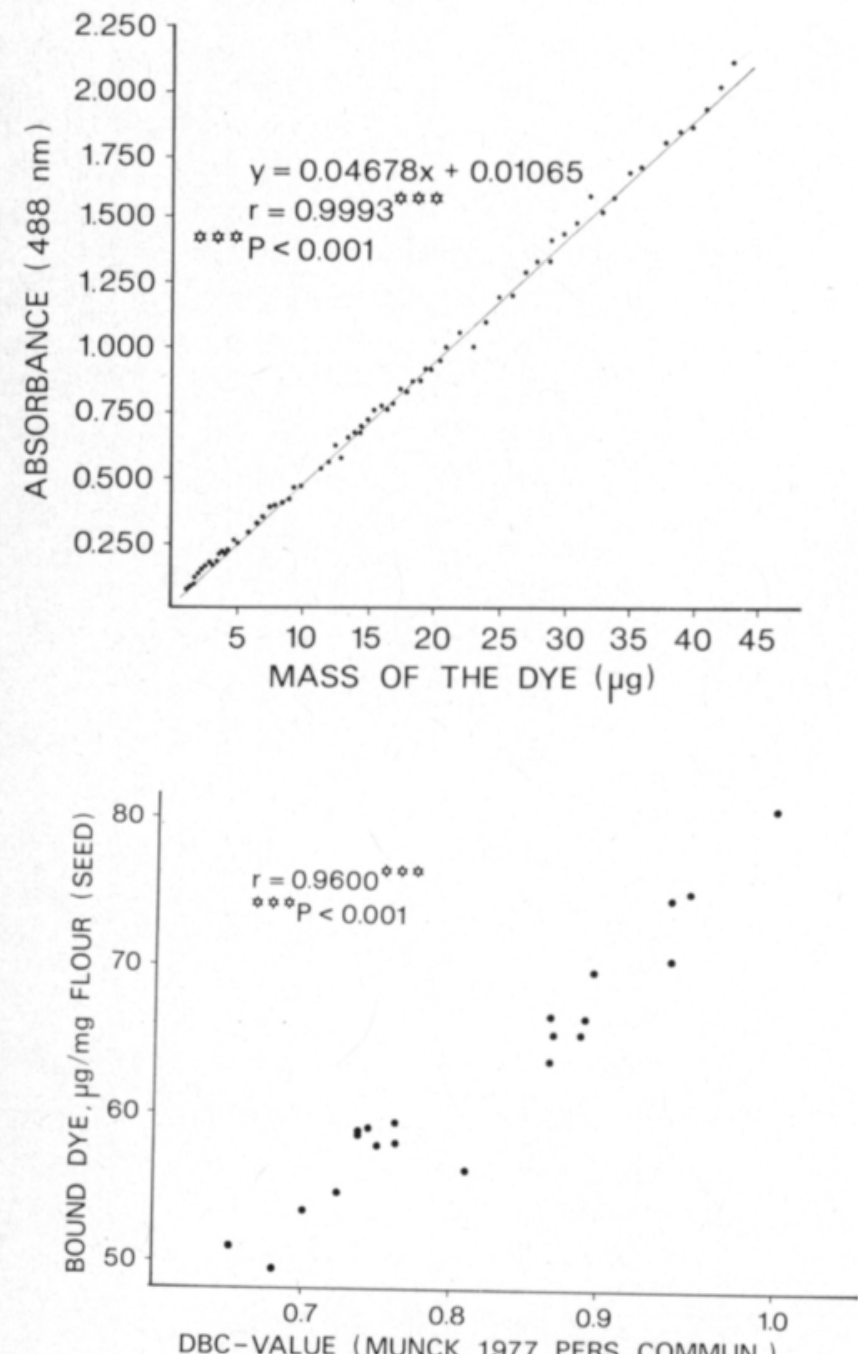

Fig. 2. The regression line between the absorbance and the mass of the dye (acid orange 12).
Fig. 3. The correlation between means of $4-12$ seeds of barley lines and the DBC-value obtained by a macro-DBC method. 
Table 2. Results of micro-DBC method compared to macro-DBC method (DBC-value $=$ the amount of bound dye, $\mathrm{mg} / \mathrm{mg}$ protein). Results of the macro-DBC analysis were kindly given to us by MUNCK at the Carlsberg laboratories.

\begin{tabular}{|c|c|c|c|c|c|c|}
\hline \multirow{3}{*}{$\begin{array}{l}\text { Barley } \\
\text { line }\end{array}$} & \multirow{3}{*}{$\begin{array}{c}\text { Number of } \\
\text { analyzed } \\
\text { seeds }\end{array}$} & \multicolumn{3}{|c|}{ Micro-DBC method } & \multirow{3}{*}{$\begin{array}{l}\text { Macro-DBC } \\
\text { method, } \\
\text { BDC-value }\end{array}$} & \multirow{3}{*}{$\begin{array}{l}\text { Protein- } \% \\
\mathrm{~N} \times 6.25\end{array}$} \\
\hline & & \multicolumn{2}{|c|}{$\begin{array}{c}\text { Amount of bound dye, } \\
\mu \mathrm{g} / \mathrm{mg} \text { (seed) flour }\end{array}$} & \multirow[t]{2}{*}{$\begin{array}{l}\text { Correlation } \\
\text { coefficient }^{1} \text { ) }\end{array}$} & & \\
\hline & & $\overline{\mathbf{x}}$ & C.V. $\%$ & & & \\
\hline 1. & 10 & 54.63 & 9.86 & -0.127 & 0.723 & 12.7 \\
\hline 2. & 11 & 57.88 & 12.00 & -0.339 & 0.763 & 13.4 \\
\hline 3. & 12 & 58.72 & 8.47 & $-0.774 * *$ & 0.738 & 13.5 \\
\hline 4. & 12 & 59.32 & 9.00 & -0.371 & 0.763 & 13.9 \\
\hline 5. & 9 & 80.62 & 6.14 & -0.527 & 1.000 & 15.3 \\
\hline 6. & 6 & 65.29 & 7.84 & -0.618 & 0.870 & 15.1 \\
\hline 7. & 4 & 57.71 & 7.69 & -0.304 & 0.751 & \\
\hline 8. & 5 & 58.58 & 8.47 & $-0.914^{*}$ & 0.738 & 13.0 \\
\hline 9. & 5 & 65.28 & 23.28 & -0.796 & 0.889 & 15.0 \\
\hline 10. & 6 & 56.09 & 4.74 & +0.125 & 0.812 & 13.2 \\
\hline 11. & 6 & 74.89 & 7.22 & $-0.889^{*}$ & 0.961 & 14.1 \\
\hline 12. & 6 & 66.63 & 10.44 & -0.524 & 0.868 & 14.4 \\
\hline 13. & 6 & 63.46 & 4.99 & -0.810 & 0.868 & 14.1 \\
\hline 14. & 6 & 70.38 & 12.36 & $-0.929 * *$ & 0.949 & 15.0 \\
\hline 15. & 6 & 74.25 & 7.81 & -0.659 & 0.949 & 15.6 \\
\hline 16. & 6 & 66.37 & 16.57 & -0.519 & 0.891 & 15.1 \\
\hline 17. & 6 & 58.98 & 6.07 & -0.333 & 0.745 & 12.5 \\
\hline 18. & 6 & 53.22 & 9.76 & -0.009 & 0.700 & 11.2 \\
\hline 19. & 12 & 49.20 & 8.45 & $-0.672^{*}$ & 0.680 & 11.3 \\
\hline 20. & 12 & 51.03 & 8.86 & $-0.689^{*}$ & 0.651 & 10.6 \\
\hline 21. & 6 & 69.57 & 10.65 & +0.152 & 0.970 & 12.9 \\
\hline
\end{tabular}

${ }^{*} \mathrm{P}<0.05, \quad{ }^{* *} \mathrm{P}<0.01$

1) Correlation coefficient between seed size and amount of bound dye.

\section{Discussion}

The DBC method has proved to be a rapid method in screening for cereal lines with high lysine content. The study of the genetic background regulating the protein content and amino acid composition of cereals has revealed that the protein content is in itself a quantitative polygenic character, but single genes have a strong influence on the lysine content of at least corn (Mertz et al. 1964, Nelson et al. 1965), sorghum (Singh and Axtell 1973) and barley (Munck et al. 1970, Doll 1973, Muench et al. 1976). Since the genes influencing the lysine content are inherited in a simple Mendelian fashion, the segregation of the lysine content is clear in the recombinants. This makes selection for the lysine content possible already in early segregating generations; on half grains in $\mathrm{F}_{2}-\mathrm{F}_{4}$ saving the embryo, or on whole grains in $\mathrm{F}_{5}$ or later saving the seeds of single idividuals. Thus mass-screening is done prior to line-selection. This is the case when lysine is determined by recessive genes in the triploid endosperm. The FP-9 Analyzer System is particularly suitable for analysis of this kind. If the selection of the lysine content is made during the early generations, all offspring lines do not need to be grown and much larger populations can be handled. The FP-9 Analyzer System, compared to 
conventional macro-DBC analyzing methods, has the advantage of requiring only 1 or $1 / 2$ grain for the analysis.

Although a high correlation exists between the means of $4-12$ seeds of barley lines and the results of Munck obtained by the macro-DBC method, the variation in dye binding within the barley lines is nevertheless quite high. AHNström (personal communication) has obtained with the micro-DBC method a coefficient of variation of $17 \%$ for threshed grain. The coefficients of variation obtained in this study, and the percentage obtained by AHnström, correspond to the total variation, which consists of the variation within a single spike, together with the variation between different spikes. Axmann (1975) has estimated that the difference between spikes is greater than the variation within a single spike. Aнnström (personal communication) has obtained a coefficient of variation of $11 \%$ within single spikes. Based on a study of 11 2-row barley varieties Fischвеск (1965) has noted that the grains at the top of the spike are the lightest and the ones in the middle are the heaviest. Correspondigly, the protein content diminishes towards the base of the spike. According to the present study there is a negative correlation between the seed size and the amount of bound dye, $\mu \mathrm{g} / \mathrm{mg}$ flour (seed) (the amount of bound dye corresponds to the basic amino acids). Pomeranz et al. (1976), however, have not noted significant differences in protein content or amino acid composition among grains in the different parts of the barley spike. Similar results have been obtained with rice, i.e. no significant differences in protein content have been noted between the seeds from different parts of the spike. On the other hand, significant differences in protein content between individuals within a variety have been found with the DBC method (MIKAELSEN and KARTOPRAWIRo 1973).

In the light of the present results, as well as of earlier studies, it is of the utmost importance that the variation in protein content and amino acid composition among individual plants resulting from environmental factors would be minimal, when the FP-9 Analyzer System is used and the DBC determination is made from a single grain. It is of less importance where in the spike the grain is located. One possibility of decreasing the variation in the protein content caused by environmental factors is to use heavy $\mathrm{N}$ fertilization. Increased $\mathrm{N}$ fertilization raises the protein content and simultaneously decreases the variation in the protein content caused by environmental factors. Thus the genetic variance of the protein content increases in relation to the total variance (UlonskA et al. 1975). Selection studies performed under powerful $\mathrm{N}$ fertilization may of course be criticized for economical reasons.

The amount of dye solution compared to the amount of flour (weight of a grain) is smaller in the FP-9 Analyzer System than in most macro-DBC methods (Mossberg 1969, Udy 1971). On the other hand, the dye concentration of the dye solution is higher. This method has been used also for single grains of wheat and rice (unpublished results). The FP-9 Analyzer System can be adapted to single or half grain DBC analysis of high protein legumes by increasing the dye concentration of the dye solution.

Acknowledgement. This work was supported by the Ministry of Trade and Industry in Finland. 


\section{REFERENCES}

Axmann, H. 1975. A semi-automatic method for mass screening basic amino acids in cereal grains by DBC. In: Breeding for Seed Protein Improvement Using Nuclear Techniques, Proc. Res. Co-ord. Meet. Ibadan, 1973, p. 145-155. IAEA, Vienna.

DoLL, H. 1973. Inheritance of the high-lysine character of a barley mutant. Hereditas 74 : 293-294.

EgGum, B. 1977. The nutritive quality of cereals. Cereal Res. Commun. 5: 153-157.

Fisснвеск, G. 1965. Properties of different corns from the same ear of barley. Brauwissenschaft 18: 1-. (Ref. Pomeranz, Y., Wesenberg, D. M., Smith, R. T., Robbins, G. S. \& Gilbertson, J. T. 1976).

Hagberg, A. \& Karlsson, K.-E. 1969. Breeding for high protein content and quality in barley. In: New Approaches to Breeding for Improved Plant Protein, Proc. Panel Röstånga, 1968, p. 17-21. IAEA, Vienna.

Kaul, A. K., Dhar, R. D., Swaminathan, M. S. \& Ahnström, G. 1969. A rapid dye-binding method of screening single grains for protein characteristics. Curr. Sci. 20:330-331.

- , Sharma, T. R., Georgi, B. \& Niemann, E.-G. 1976. Further developments in the rapid determination of nitrogen, lysine and tryptophan content in cereals. In: Evaluation of Seed Protein Alterations by Mutation Breeding, Proc. 3th Res. Co-ord. Meet. Hahnenklee, 1975 p. 27-43. IAEA, Vienna.

Mertz, E. T., Bates, L. S. \& Nelson, O. E. 1964. Mutant gene that changes protein composition and increases lysine content of maize endosperm. Science 145: 279-280.

Mikaelsen, K. \& Kartoprawiro, M. I. 1973. Studies on inter- and intraplant variation in seed protein content of rice. In: Nuclear Techniques for Seed Protein Improvement, Proc. Res. Co-ord. Meet. Neuherberg, 1972, p. 199-202. IAEA, Vienna.

Mossberg, R. 1969. Evaluation of protein quality and quantity by dye-binding capacity: a tool in plant breeding. In: New Approaches to Breeding for Improved Plant Protein, Proc. Panel Röstånga, 1968, p. 151-160. IAEA, Vienna.

Muench, S. R., Lejeune, A. J., Nilan, R. A. \& Kleinhofs, A. 1976. Evidence for two independent high lysine genes in barley. Grop Sci. 16: 283-285.

Munck, L., Karlsson, K.-E., Hagberg, A. \& Eggum, B. O. 1970. Gene for improved nutritional value in barley seed protein. Science 168: 985-987.

Nelson, O. E., Mertz, E. T. \& Bates, L. S. 1965. Second mutant gene affecting the amino acid pattern of maize endosperm proteins. Science 150: 1469-1470.

Pomeranz, Y., Wesenberg, D. M., Smith, R. T., Robbins, G. S. \& Gilbertson, J. T. 1976. Amino acid composition of barley kernels from different parts of the spike. Cereal Chem. 53: 839-845.

SAUER, W. C. 1976. Factors affecting amino acid availabilities for grains and their components for growing monogastric animals. Thesis. The Faculty of Graduate and Research. University of Manitoba. Canada. (Ref. Eggum, B. 1977).

Singh, R. \& Axtell, J. D. 1973. High lysine mutant gene (hl) that improves protein quality and biological value of grain sorghum. Crop Sci. 13:535-539.

Suovaniemi, O. 1976. Performance and properties of the Finnpipette analyzer system. In: Proc. 2nd Natl. Meet. Biophys. Biotechnol. Finland, p. 183-187. Ed. A.-L. Kairento, E. Riihimäki \& P. Tarkka.

TAllberg, A. 1976. Some aspects of screening methods for high lysine barley. In: Evaluation of Seed Protein Alterations by Mutation Breeding, Proc. 3th Res. Co-ord. Meet. Hahnenklee, 1975, p. 19-25. IAEA, Vienna.

Udy, D. C. 1971. Improved dye method for estimating protein. J. Am. Oil Chem. Soc. 48: $29 \mathrm{~A}-33 \mathrm{~A}$.

Ulonska, E., GaUl, H. \& Baumer, M. 1975. Investigation of selection methods in mutation breeding of barley for protein quantity and quality. In: Breeding for Seed Protein Improvement Using Nuclear Techniques, Proc. Res. Co-ord. Meet. Ibadan, 1973, p. 61-77. IAEA, Vienna.

Ms received April 19, 1979 


\title{
Puoliautomaattinen analysaattorijärjestelmä mikro-DBC-menetelmälle emäksisten aminohappojen tutkimiseksi yhdestä jyvästä
}

\author{
Marketta Saastamoinen ja P. M. A. Tigerstedt \\ Finnpipette Ky|Labsystems Oy. Pulttitie 9, 00810 Helsinki 81 ja Kasvinjalostustieteen laitos, \\ Helsingin yliopisto, 00710 Helsinki 71.
}

Kehitetty yhden siemenen mikro-DBC-menetelmä perustuu FP-9 analysaattorijärjestelmään, joka on alunperin kehitetty lääketieteellisiä tutkimuksia varten. Muutamien lisälaitteiden avulla järjestelmä on sovellettu käytettäväksi siemenproteiinien mikro-DBC-menetelmässä. Menetelmän avulla pystytään analysoimaan yhden jyvän sitoma väriainemäärä (acid orange 12) jyvän painoyksikköä kohden.

FP-9 analysaattorijärjestelmässä 9 näytettä käsitellään kaikissa työvaiheissa samanaikaisesti. Järjestelmä käsittää vaa'an, 9-kärkiset pipetit, 9-kärkisen automaattilaimentimen, myllyn 9 jyvälle, sekoittajan $8 \times 9$ näytteelle, sentrifuugin $4 \times 9$ näytteelle ja fotometrin 9 näytteelle sekä siihen kytketyn ohjelmoitavan laskimen. Suurin pipetoitava nestemäärä on $1 \mathrm{ml}$.

Tri. L. Munck'in (Carlsbergin laboratorio, Tanska) lähettämät 21 ohralinjaa tutkittiin FP-9 analysaattorijärjestelmällä. Kustakin ohralinjasta tutkittiin 4-12 jyvää. Niiden keskiarvojen ja makro-DBC-menetelmällä saatujen tulosten väliseksi korrelaatiokertoimeksi (r) saatiin $0.9600^{* * *}$. Ohralinjojen sisäistä vaihtelua kuvaava vaihtelukerroin (C. V. \%) oli 4.74$23.28 \%$. Homogeenista standardijauhoa käytettäessä vaihtelukerroin oli $1.81-3.79 \%$. Menetelmä on kehitetty ennenkaikkea kasvinjalostuksen tarpeita ajatellen. Mikro-DBCmenetelmällä voidaan suorittaa analyysi yhdestä tai puolesta jyvästä segregoituvissa aikaisissa sukupolvissa $\left(\mathrm{F}_{2}-\mathrm{F}_{5}\right)$, jolloin vältytään suurien materiaalien viljelemiseltä. 